\title{
Implementation of the Government Credit Card Policy in the Ministry of Foreign Affairs of the Republic of Indonesia
}

\author{
Paramita Nur Kurniati ${ }^{1}$, Bernardus Yuliarto Nugroho ${ }^{2}$, Ferdinand D. Saragih ${ }^{3}$ \\ \{paramita.kurniati@gmail.com ${ }^{1}$, nugroho_yuliarto@yahoo.com ${ }^{2}$, saragih_fds@yahoo.com ${ }^{3}$ \} \\ ${ }^{1,2,3}$ Faculty of Administrative Science, University of Indonesia, Jakarta, Indonesia
}

\begin{abstract}
The successful implementation of the policy on the use of Government Credit Cards can be seen from the content of the policy and the context of policy implementation. This research is using post positivism approach with qualitative as research method. The results of the study show, based on the content of the policy the preparation of each working unit is still necessary to improve to close the gaps and potential risks that may arise. In terms of aspects of the context of policy implementation, the use of Government Credit Cards into a form of innovation and new breakthroughs that require continuous improvement while taking into account the political and governmental conditions that are in power, and require support from other relevant Ministries / Agencies. Government Credit Card as a modern financial instrument play a role to support the management of state financial liquidity.
\end{abstract}

Keywords: Cashless government, content of policy, context of implementation, government credit cards, policy implementation, public sector innovation.

\section{Introduction}

The phenomenon of advancement in the field of financial technology that occurs throughout the world is unavoidable, where transaction settlement is required to be easier, faster, safer, more practical and reliable. This phenomenon changes the paradigm of the payment system in a conventional way that relies on physical money as a payment instrument shifting to non-cash instruments. To respond to this phenomenon, the Indonesian Government in this case the Ministry of Finance seeks to design a cashless government system in the management of state finances.

The concept of cashless government itself is actually adopted from the cashless society concept. Bintarto [1] states that a cashless society is a term that refers to people who in transactions, no longer use physical money, but through the transfer of digital financial information (digital money). In line with this, the concept of cashless government is intended to minimize the use of physical money, from cash base to cashless, and gradually replace the payment system process from manual to digital.

Viewed from the macro aspect, R. Maulana Ibrahim in the International Seminar "Towards Less Cash Society in Indonesia" held by Bank Indonesia [2] said that the function of the payment system was very critical in an economy. The payment system is likened to a blood stream that moves and launches the organs of the economy to ensure the stability of the financial system. Any distortions that arise in the payment system will disrupt the transmission of liquidity in the economy. 
Therefore, in order to create financial system stability and the effectiveness of monetary policy, the Government of Indonesia issued a policy on the use of Government Credit Cards (Kartu Kredit Pemerintah - KKP) as a modern payment instrument in government spending. These transactions include transactions for official travel expenditure, operational goods expenditure, non-operational goods expenditures, inventory purchases, rental and maintenance expenditures.

Based on Government Regulation Number 50 Year 2018 concerning Amendments to Government Regulation Number 45 of 2013 concerning Procedures for Implementing the State Revenue and Expenditure Budget article 2a [3], it is stated that the mechanism of the Money Supply (which was originally only managed using cash, checks and bilyet giro) is began to be shifted towards cashless by using payment instruments in the form of credit cards, debit cards, and internet banking.

In 2017, the Ministry of Finance issues Director General of Treasury Regulation Number 17 / PB / 2017 [4] and Decree of the Director General of Treasury Number Kep-494 / PB / 2017 [5] concerning Trial Implementation of Credit Card Payments in the framework of Using Inventory Money. The first phase is held from October to December 2018 and is tested on 6 (six) Work Units (Satuan Kerja - Satker). Furthermore, the second phase will be held no later than November to December 2018 and will be tested on all vertical satker of the Directorate General of Treasury. The third stage was implemented in 83 Satker. The fourth stage was carried out on 25 Working Units. The fifth stage was implemented in 46 Working Units. Sixth stage on 72 Satker. As well as the final stage, it is expected that from 1 July 2019 all working units that use the State Budget (Anggaran Pendapatan dan Belanja Negara - APBN) have fully implemented the Government Credit Card.

Meanwhile, the procedure for payment and use of Government Credit Cards is regulated in the Regulation of the Minister of Finance Number PMK 196 / PMK.05 / 2018 concerning Procedures for Payment and Use of Government Credit Cards [6]. This regulation comes into force on July 1, 2019, but it can be used as a guideline for the Work Unit in the "intermediate period".

Based on data from the Ministry of Finance of the Republic of Indonesia, the Ministry of Foreign Affairs of the Republic of Indonesia is the first Ministry to simultaneously implement a policy on the use of Government Credit Cards at its 14 Satker at the Center. Transactions through Government Credit Cards in the Ministry of Foreign Affairs is expected to be able to minimize the use of cash (physically), improve state financial liquidity, and support better government cash planning. The use of Government Credit Cards is expected to also increase transparency and accountability in the use of state budget. The payment system using a credit card instrument makes it possible to be traced and tracked in full and in detail, starting from who the user is, when and where the transaction is carried out, what is the purpose of using the transaction, and how much.

Viewed from the description above, the researchers felt interested in conducting a comprehensive and in-depth study of how this policy was implemented in the Ministry of Foreign Affairs of the Republic of Indonesia. In addition, researchers want to identify the factors that encourage and inhibit public sector innovation in payment systems, especially with the use of Government Credit Cards (KKP). The Merille S. Grindle Policy Implementation Model [7] will be used by researchers as an analysis knife because the model offered by Grindle is a comprehensive model, which starts from the steps to understand the policy itself [8]. 


\section{Research Methods}

The approach used in this study is a post-positivist because it does not separate theory from social phenomena, but integrates theory with empirical facts. The research method used is descriptive qualitative research method. While the data collection techniques used are indepth interview techniques and documentation studies. The key informants interviewed were from the Finance Bureau and the Strategic Support Bureau of the Ministry of Foreign Affairs of the Republic of Indonesia. Whereas the documentation study was carried out through official documents on finance at the Ministry of Foreign Affairs of the Republic of Indonesia.

\section{Discussion}

The approach used in this study is a post-positivist because it does not separate theory from social phenomena, but integrates theory with empirical facts. The research method used is descriptive qualitative research method. While the data collection techniques used are indepth interview techniques and documentation studies. The key informants interviewed were from the Finance Bureau and the Strategic Support Bureau of the Ministry of Foreign Affairs of the Republic of Indonesia. Whereas the documentation study was carried out through official documents on finance at the Ministry of Foreign Affairs of the Republic of Indonesia.

\subsection{The Cashless Society and Cashless Government Concept}

Money and payment systems are increasingly growing along with the times. In an era where technology is advancing rapidly, people are faced with the challenge of a cashless society. In this case, money is seen as a tool and is not a mere physical entity.

With this kind of payment system, people do not use physical money but virtual money or transfer financial information digitally. The concept of a cashless society which was then tried to be adopted in the payment transaction system of the government which was initially carried out in cash was then shifted to cashless so that later it was called cashless government.

\subsection{Policy Implementation}

B. Guy Peters and Jon Pierre in the book Handbook of Public Policy [9] states that: "Implementation is a relatively young research field in public administration and public policy. The field has made an important contribution in terms of adding a public policy perspective to public administration, with a strong focus on how policies are transformed during the execution process till - and even after - the point of delivery. The research is valuable for our understanding of the complexities of policy implementation. The studies have revealed many important barriers for implementation as well as factors that may make success more likely."

Grindle (1980) mentions two factors that determine the success of policy implementation namely the content of policy and the context of implementation. The content of policy consists of variables: (1) Interest Affected; (2) Type of Benefits; (3) Extent of Change Envision; (4) Resources Committed; (5) Program Implementer; and (6) Site of Decision Making. Whereas the context of implementation consists of variables (1) Power, Interest, and Strategy of Actors Involved); (2) Institution and Regime Characteristics; and (3) Compliance and Responsiveness. 


\subsubsection{Content of Policy}

Interest affected is related to various interests that influence a policy implementation. The success or failure of a policy implementation is influenced by the extent to which it can understand and apply the benefits of a policy content. The Ministry of Foreign Affairs is one of the ministries that supports the national digitalization program launched by the Government, especially in the financial sector, by involving all 14 working units. With the increasing participation of the Work Unit that implements this policy, it is hoped that it will be able to further reduce the amount of cash in circulation and towards automation of payments and further increase the country's financial liquidity.

Type of benefits strive to show or explain that in a policy there must be several types of benefits generated by the implementation of policies implemented. The use of credit cards will will bring benefits: (1) suppressing the idle cash and cost of funds in state finance so that it is expected to increase the country's financial liquidity; (2) reduce the cost handling of cash such as the cost of issuing, distributing, and maintaining physical cash; (3) reducing the risk of potential corruption, the use of counterfeit money or the potential loss of physical cash; and (4) minimizing the risk of obstructing office operations due to problems of availability or money readiness in government agencies. In addition, the use of Government Credit Card instruments also makes transaction settlement faster, more accurate, safer, and more transparent and accountable.

Extent of change envision is the degree of change of a policy in an organization or each individual. The use of the Government Credit Card is expected to be able to change the mindset and paradigm of the State Civil Apparatus which used to use a conventional payment system to become a cashless payment system. However, these changes can not be separated from resistance from within the organization such as the resistance of individuals and organizations, as well as from outside the organization. Individual resistance is caused by lack of understanding in using the Government Credit Card. Resistance is also related to "habits" in organizations that always carry "oleh-oleh" after carrying out official travel and the existence of "uang laki-laki" or "uang emak-emak". Organizational resistance is caused by the reluctance to use the instrument because it feels that the accounting system has become more complicated and there are fears of not getting the predicate of Unqualified in financial report. Resistance outside the organization comes from suppliers of goods and services that do not have EDC machines and tend to prefer the principle of "cash and carry". In addition, the current tax system still cannot adjust the cashless payment system.

Site of decision making that each decision will consider the authority of the decision maker and will have an impact on the level of implementation of the policy. Strategic level decision making is carried out by Echelon I as the Budget User Authority (Kuasa Pengguna Anggaran - KPA) while the technical level decision making can be completed by the Financial Authorizing Officer (Pejabat Pembuat Komitmen - PPK).

Program Implementer of this policy is the KKP holder, administrator, and financial management officials including the treasurer, PPK and KPA. Resources Committed are resources that are devoted to supporting policy implementation. The Ministry of Foreign Affairs has devoted the support of facilities and infrastructure and financial support sourced from its budget. The support is used for socialization, focus group discussions, technical guidance activities and evaluation meetings in order to increase understanding of the implementation of the state budget by using Government Credit Card payment instruments.

\section{Context of Implementation}

Power, Interests, and Strategies of Actors Involved, in a policy also needs to be taken into account the strength or power, interests, and strategies used by the actors involved to 
facilitate the implementation of a policy implementation. The Ministry of Foreign Affairs itself is one of the ministries that supports the financial digitalization program that is proclaimed nationally. To support the program, the Ministry of Foreign Affairs specifically launched the hashtag "Digitizing Budget Management" to change from manual (paper based) systems become a digital system.

Institution and Regime Characteristic the policy of using Government Credit Cards is in line with the administrative system arrangement, especially in the field of finance within the Ministry of Foreign Affairs, which began in 2001, when the "Program Benah Diri" was launched. At that time, the Ministry of Foreign Affairs established a work culture known as 3T and $1 \mathrm{~A}$, which stands for administrative order, orderly time, physical discipline, and safe personnel-information-work environment towards a better, participatory, innovative, professional and accountable. This commitment is shown by the Deputy Minister of Foreign Affairs who actively participates in all stages of preparations that have been determined for the implementation of the policy. The Deputy Minister of Foreign Affairs also takes a personal approach to Echelon I officials within the Ministry of Foreign Affairs to use cashless payment instruments.

Compliance and Responsiveness The Ministry of Foreign Affairs is the first Ministry to implement the Government Credit Card policy simultaneously and is prepared in its entirety since August 7, 2018. The acceptability level of using Government Credit Cards since its inception has shown an increasing trend, seen from the number of credit cards issued and the volume of transactions carried out.

\section{Conclusion}

There are still things that need to be improved in the framework of implementing Government Credit Cards. These include: (1) availability of facilities and infrastructure in the form of Electronic Data Capture (EDC) machines, internet network stability and network / electricity supply stability; (2) the development of a taxation system and an accounting and reporting system to accommodate cashless transactions; and (3) adjusting audit audit procedures. Furthermore, public sector organizations must foster self-urgency and the level of organizational and individual readiness (such as digital literacy and financial literacy) to accept changes in order to adapt to changing times and meet public demands for public transparency and accountability.

\section{References}

[1] E. A. Bintarto, Fintech dan Cashless Society: Sebuah Revolusi Pendongkrak Ekonomi Kerakyatan. Surabaya: Universitas Airlangga, 2018.

[2] Bank Indonesia, "Seminar Internasional 'Towards a Less Cash Society in Indonesia," 2006.

[3] Government Regulation Number 50 Year 2018 concerning Amendments to Government Regulation Number 45 of 2013 concerning Procedures for Implementing the State Revenue and Expenditure Budget (2018). .

[4] Director General of Treasury Regulation Number 17 / PB / 2017 (2017). .

[5] Decree of the Director General of Treasury Number Kep-494 / PB / 2017 (2017). .

[6] Regulation of the Minister of Finance Number PMK 196 / PMK.05 / 2018 concerning Procedures for Payment and Use of Government Credit Cards (2018). .

[7] M. S. Grindle, Politics and Policy Implementation in the Third World. New Jersey: 
Princeton University Press, 1980.

[8] Y. Nurfakhrana, Analisis Efektivitas Implementasi Kebijakan Pengembangan Kawasan Minapolitan di Kabupaten Bintan Provinsi Kepulauan Riau. Depok: Universitas Indonesia, 2015.

[9] B. G. Peters and J. Pierre, Handbook of Public Policy. 2006. 